\title{
PROSES TRANSLASI REPRESENTASI ALJABAR KE GRAFIK
}

\author{
Prayogo \\ Program Studi Pendidikan Matematika, Universitas PGRI Adi Buana Surabaya \\ Email: prayogounipa@gmail.com
}

\begin{abstract}
Abstrak:
Penelitian eksploratif dengan pendekatan kualitatif digunakan dalam penelitian ini dengan tujuan menggambarkan proses translasinya secara alami. 42 siswa SMP kelas VIII terlibat dalam penelitian ini, dan 15 siswa berada pada kategori kemampuan rendah. Subjek dipilih berdasarkan siswa kemampuan rendah yang mampu berkomunikasi dengan baik, yaitu ARD. Hasil penelitian menunjukkan bahwa dalam mengubah representasi aljabar ke grafik melibatkan dua metode berbeda, yaitu representasi simbolik terlebih dahulu baru menuju representasi grafik. Representasi simbolik digunakan ARD pada proses unpacking source, preliminary coordination, construction the target, dan determination of equivalent. Sedangkan representasi grafik digunakan ARD ketika mengonstruksi masalah target sesuai dengan keinginan dari masalah.
\end{abstract}

Kata Kunci: Representasi, Aljabar, Grafik

\section{Pendahuluan}

Representasi merupakan alat untuk membangun dan mengomunikasikan ide dan pemahaman matematika. Seperti yang diungkapkan Bruner bahwa representasi terdiri atas tahapan enaktif, ikonik, dan simbolik. Proses transisi antara satu representasi ke representasi lainnya tentunya melibatkan proses kognitif (AduGyamfi, Stiff, \& Bosse, 2012)

Lebih lanjut, Lesh, Post, \& Behr (1987) menjelaskan translasi yang melibatkan berbagai representasi menunjukkan pemahaman yang dimiliki siswa. Pemahaman tersebut didasarkan pada (1) mengingat ide dari sistem representasi yang berbeda, (2) fleksibel dalam memanipulasi ide dalam berbagai sistem representasi, dan (3) translasi ide dari satu sistem ke sistem yang lainnya.

Aktivitas translasi merupakan komponen penting dalam proses pembelajaran untuk mengekspresikan ide matematika (Bal, 2014). Hal ini diperkuat oleh (NCTM, 2000) yang menyarankan siswa agar dapat menentukan pilihan, mengaplikasikan dan melakukan translansi representasi ketika melakukan proses pemecahan masalah.

Dari penelitian Gagatsis \& Shiakalli (2004) menunjukkan bahwa kemampuan siswa dalam melakukan translasi representasi masih rendah.
Penelitian tentang representasi telah banyak dilakukan oleh beberapa peneliti diantaranya Anwar \& Rahmawati (2017); Sari \& Rosjanuardi (2018); Surya, dkk. (2013); Boose, Adu-Gyamfi, \& Chandler (2014); dan masih banyak peneliti lainnya. Penelitian Anwar \& Rahmawati (2017) membahas tentang proses konstruksi representasi visual dan simbolik dalam proses memecahkan masalah. Hasilnya menunjukkan bahwa dalam proses memecahkan masalah masing-masing tahap menggunakan representasi yang berbeda.

(2018) menunjukkan kemampuan representasi siswa merupakan indikator pemecahan masalah yang menggunakan simbol aritmetika atau dikenal sebagai representasi simbolik. Selain itu, kesalahan yang dilakukan siswa merupakan indikator menggambarkan situasi nyata untuk mengklarifikasi masalah dan memfasilitasinya atau dikenal sebagai representasi visual.

Surya dkk (2013) meneliti tentang kemampuan representasi dalam memecahkan masalah matematika melalui CTL. Hasilnya menunjukkan pendekatan CTL dapat meningkatkan kemampuan representasi siswa baik dengan kategori tinggi, sedang, dan rendah. Penelitian lain yang dilakukan oleh (Boose, dkk., 2014) tentang translasi representasi dari grafik ke 
simbolik. Hasil penelitian ini menunjukkan bahwa proses translasi merupakan komponen penting untuk mengevaluasi proses pemecahan masalah yang melibatkan translasi representasi.

Penelitian ini penting untuk dilakukan karena penelitian terdahulu (Boose et al., 2014) menunjukkan proses translasi representasi dari grafik ke simbolik. Tetapi belum ada penelitian tentang proses translasi representasi aljabar ke grafik seperti yang akan dibahas oleh peneliti.

Penelitian ini memilih siswa dengan kemampuan rendah, tujuannya memberikan masukan bagi guru untuk menghadapi siswa dengan kemampuan rendah. Siswa dengan kemampuan rendah perlu mendapatkan perhatian dari guru supaya dapat berhasil dalam proses pembelajaran di kelas.

\section{Metode Penelitian}

Penelitian eksploratif dengan pendekatan kualitatif digunakan dalam penelitian ini. Tujuannya adalah untuk memperoleh gambaran proses translasi representasi aljabar ke grafis.

Subjek penelitian ini 42 siswa SMP kelas VIII. Pertama-tama, siswa diberikan lembar masalah untuk mengelompokkan kemampuannya, terdiri atas kemampuan tinggi, sedang, dan rendah. Dari siswa yang memiliki kemampuan rendah kemudian dipilih satu siswa yang mampu berkomunikasi dengan baik dan melakukan proses translasi representasi dari aljabar ke grafik. Siswa tersebut diberikan lembar masalah persamaan garis lurus (MPGL) dan diminta untuk think aloud ketika memecahkannya selama 60 menit. MPGL yang digunakan dalam penelitian ini antara lain:

Diketahui garis g melalui titik $A(0, b)$ dan titik $B(4,7)$. Garis $g$ tegak lurus dengan garis $h$ yang persamaannya $3 y=-4 x-6$.

Gambarkan kedua garis tersebut!

Dari hasil think aloud, peneliti mengklarifikasinya melalui wawancara semi terstruktur. Tujuannya untuk mendapatkan penjelasan dari pekerjaannya yang tidak dipahami oleh peneliti. Hasil dari kedua metode tersebut kemudian dianalisis peneliti untuk mendapatkan deskripsi proses translasi representasi aljabar ke grafik. Adapun aktivitas translasi yang digunakan dalam penelitian mengadaptasi dari Boose, dkk. (2014) \& Swastika, dkk. (2020) sebagai berikut.

Tabel 1: Aktivitas Translasi Representasi

\begin{tabular}{|c|c|}
\hline $\begin{array}{l}\text { Unpacking } \\
\text { source } \\
\text { Preliminary } \\
\text { Coordination }\end{array}$ & $\begin{array}{l}\text { Mengidentifikasi } \\
\text { informasi pada masalah } \\
\text { - Mengoneksikan } \\
\text { informasi pada tahap } \\
\text { unpacking source } \\
\text { dengan konsep yang } \\
\text { dipahami } \\
\text { - Menyiapkan informasi } \\
\text { tambahan yang dapat } \\
\text { digunakan membangun } \\
\text { representasi sasaran } \\
\text { - Membangun jaringan } \\
\text { dan mengaitkan ide } \\
\text { antar representasi }\end{array}$ \\
\hline $\begin{array}{l}\text { Construction } \\
\text { the Target }\end{array}$ & $\begin{array}{l}\text { - Translasi informasi } \\
\text { yang memuat } \\
\text { representasi aljabar ke } \\
\text { grafik } \\
\text { - Melengkapi penjelasan } \\
\text { pada representasi grafik }\end{array}$ \\
\hline Determination & - Verifikasi informasi \\
\hline
\end{tabular}

Triangulasi data dilakukan dengan tujuan mendapatkan data yang valid. Triangulasi data merupakan cara untuk memeriksa keabsahan data dengan memanfaatkan hal lain diluar data yang ada (Sugiyono, 2018). Triangulasi metode digunakan peneliti dalam penelitian ini dengan membandingkan antara hasil pekerjaan subjek, hasil think aloud, dan hasil wawancara.

\section{Hasil dan Pembahasan}

Dari hasil pekerjaan siswa diperoleh hasil seperti pada tabel 2 berikut.

Tabel 2: Kemampuan Matematika

\begin{tabular}{cc}
\hline Kategori Kemampuan & Calon Subjek \\
\hline Tinggi & 5 \\
Sedang & 22 \\
Rendah & 15 \\
\hline
\end{tabular}


Satu subjek berkemampuan rendah dipilih untuk dijadikan subjek penelitian. Subjek diberikan waktu 60 menit untuk memecahkan MPGL dilanjutkan dengan wawancarai berdasarkan aktivitas translasi. Subjek yang diambil adalah ARD, siswa kelas VIII SMP Swasta di Mojokerto, berusia 14 tahun, berada pada kategori kemampuan rendah, dan mampu berkomunikasi dengan baik.

Adapun deskripsi subjek ARD dalam melakukan proses translasi representasi dari aljabar ke grafik sebagai berikut.

\section{Unpacking Source}

Langkah awal yang dilakukan ARD adalah membaca masalah yang diberikan dengan suara pelan. ARD langsung mengetahui informasi penting yang termuat dalam masalah, kemudian secara verbal menuliskannya dalam lembar jawaban. Hal ini menunjukkan bahwa ARD melakukan proses translasi dalam bentuk representasi verbal yaitu menuliskan informasi yang diketahui dan ditanya. Hasil pekerjaan ARD dalam proses unpacking source sebagai berikut.

\section{Gambar 1. Unpacking source}

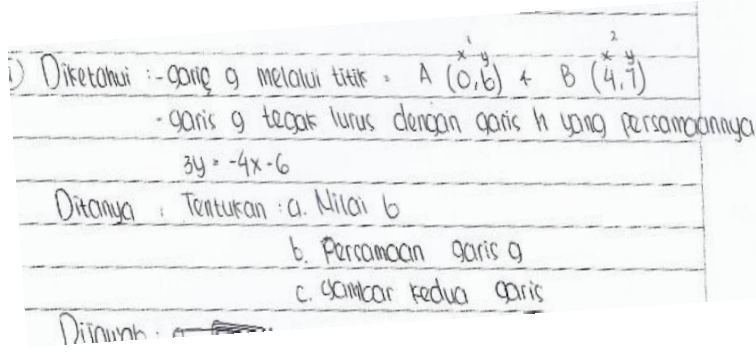

Hasil pekerjaan ARD di atas senada dengan hasil wawancara peneliti dengan ARD, seperti kutipan berikut.

$\mathrm{P} \quad$ Apa yang kamu pahami?

ARD Garis $g$ kan melalui dua titik, yang pertama $\mathrm{A}(0, \mathrm{~b})$ yang kedua B $(4,7)$. Kemudian garis $g$ tegak lurus dengan garis $h$. Garis $h$ persamaannya $3 y=-4 x-6$.

P Ada lagi?

ARD Disuruh mencari nilai $b$ terus persamaan garis g sama gambar kedua garis

\section{Preliminary Coordination}

ARD menyiapkan informasi tambahan yang dapat digunakan membangun representasi sasaran yaitu menentukan gradien garis $h$. Pekerjaan ARD dalam proses ini sebagai berikut.

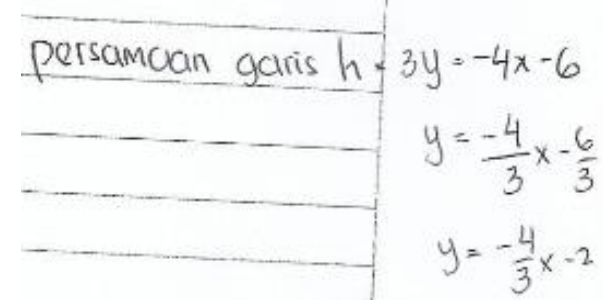

Gambar 2. Preliminary Coordination Kemudian ARD mengoneksikan informasi pada tahap sebelumnya dengan tahap unpacking source. Selain itu, ARD juga membangun jaringan dan mengaitkan ide antar representasi. Dalam hal ini ARD menerjemahkan "garis $g$ tegak lurus dengan garis $h$ " sebagai perkalian antar gradien garis sama dengan -1. Pekerjaan ARD dalam proses ini sebagai berikut.

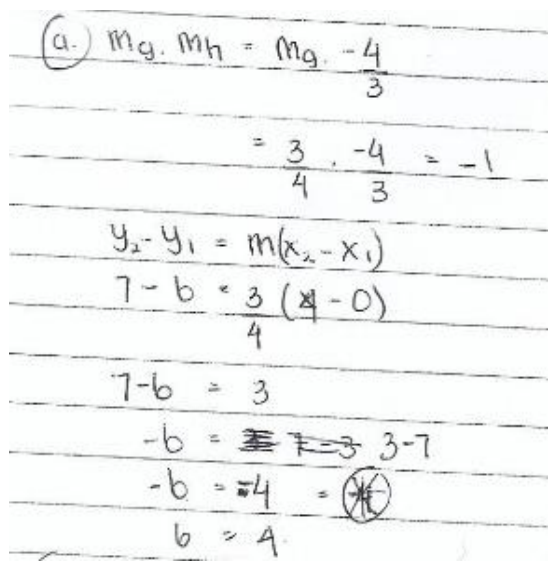

Gambar 3. Preliminary Coordination

Hasil pekerjaan ARD di atas senada dengan hasil wawancara peneliti dengan ARD seperti kutipan berikut.

P Jadi gradien tadi kemiringan garis. Garis $g$ dan $h$ bagaimana kedudukannya?

ARD Tegak lurus

P Terus sama dengan -1 kenapa?

ARD Rumus kalau $m g$ kali $m h$ itu haruslah -1. Karena gradien $h$ itu diketahui $-4 / 3$, kalau -1 dibalik jadi $3 / 4$ dikali $4 / 3=-1$ 
Dalam hal ini, ARD melakukan kesalahan menentukan nilai $b$, karena salah memanipulasi simbol yang ada. Kesalahan yang dilakukan ARD diklarifikasi melalui wawancara antara peneliti dengan ARD berikut.

$\mathrm{P} \quad$ Terus ini disuruh mencari nilai apa

ARD Mencari nilai $b, 7-b=3 / 4(4-0)$, ketemu $7-b=3 \ldots$

(Subjek bingung menentukan nilai $b$, tetapi dengan sedikit intervensi dapat diperoleh nilai $b$ yang benar yaitu $b=4$ )

P Kenapa kok ketemu 4?

ARD Karena negatip ketemu negatip , 1 dikali -4 sama dengan 4 . $-b=-4, b=-1 \times-4=4$ (subjek mengucapkan negatip $b$ sama dengan ... dan seterusnya)

Setelah menentukan nilai $b, \quad$ ARD membangun jaringan dan mengaitkan ide antar representasi yaitu menentukan persamaan garis $g$. Pekerjaan ARD dalam proses ini sebagai berikut.

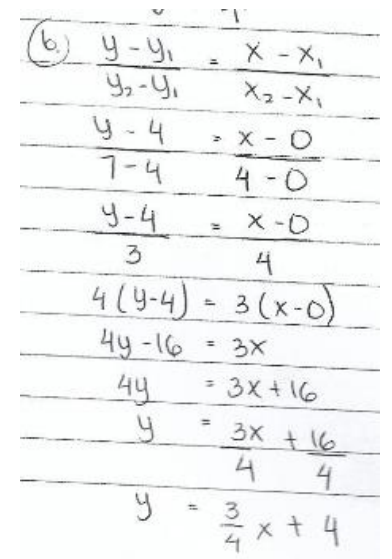

Gambar 4. Preliminary Coordination

\section{Construction the Target}

Setelah menentukan persamaan garis $g$, ARD menggambarkan grafik garis $g$ dan $h$. Langkah awal yang dilakukan oleh ARD yaitu menggambarkan garis $h$. Pada awalnya, ARD mengalami kebingungan dalam menggambarkannya. Akhirnya ARD menentukan dua buah titik yang melalui garis $h$ yaitu titik $(0,-2)$ dan $(3,-6)$. Kebingungan yang dialami ARD seperti pada kutipan wawancara berikut.

\author{
P Gimana caranya gambar? \\ Mencari apa dulu? \\ ARD Titik \\ P Berapa titiknya? \\ ARD Banyaknya dua (Subjek bingung \\ untuk menggambar grafik garis $h$ \\ dan menentukan dua titik yang \\ melalui garis $h$ ).
}

Untuk menggambarkan garis $g$, ARD menentukan dua titik yang melaluinya dengan memanfaatkan nilai $b$ yang telah ditemukan sebelumnya yaitu titik A $(0,4)$ dan B $(4,7)$. Melalui kedua titik tersebut, ARD melengkapi penjelasan pada grafik untuk menunjukkan antara garis $g$ saling tegak lurus dengan garis $h$. Adapun pekerjaan ARD dalam mengonstruksi target menggambarkan grafik sebagai berikut.

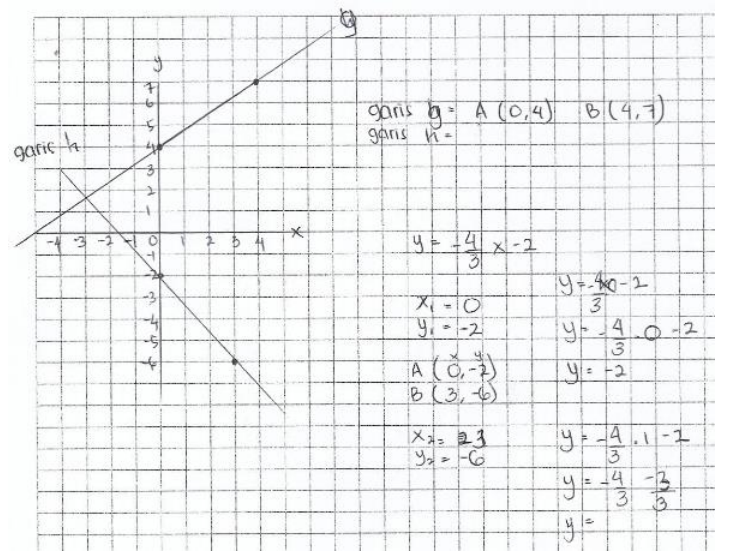

Gambar 5. Construction the Target

\section{Determination of Equivalent}

Pada tahap ini, ARD memverifikasi representasi yang dihasilkan yaitu grafik. Verifikasi ini diperjelas ARD melalui proses wawancara yang dilakukan peneliti seperti pada kutipan wawancara berikut.

$\mathrm{P} \quad$ Terus diapakan?

ARD Bisa mencari titik garis $g$. persamaan garis $g$....

$P \quad$ Mencari $x$ nya itu sembarang atau bagaimana?

ARD Sembarang, kelipatan 4 atau 3, kebetulan itu gradiennya

Proses unpacking source yang dilakukan oleh ARD senada dengan pendapat Boose, dkk. (2014) pada aktivitas translasi yang dimulai dengan informasi 
termuat dalam masalah dan mengidentifikasi informasi yang diketahui, pertanyaan pada masalah, dan informasi yang tidak muncul pada masalah. Proses identifikasi masalah tujuannya untuk mengidentifikasi yang diketahui pada masalah dan pertanyaan yang muncul sama seperti tahapan awal pemecahan masalah yang disajikan oleh Polya (1973) yaitu memahami masalah.

Proses translasi yang dilakukan ARD pastinya berkaitan dengan konsep sebelumnya (Swastika, dkk., 2020), yaitu tentang gradien, persamaan garis lurus, menggambar grafik. Pada tahap preliminary coordination dan construction the target, cara yang dilakukan siswa dapat bermacammacam. Seperti yang dilakukan oleh ARD yaitu menentukan gradien garis $h$. Barulah ARD menentukan nilai $b$ yang merupakan dua titik yang dilalui oleh garis $g$. Setelah informasi yang dibutuhkan lengkap ARD menggambarkan garis $h$ dengan bantuan dua titik yang melalui garis $h$. Disinilah ARD dapat menggambarkan garis $g$ saling tegak lurus dengan garis $h$.

Ketika ARD melakukan kesalahan, ARD cepat menanggapi dengan melakukan perubahan, seperti pada hasil wawancara peneliti dengan subjek. Kesadaran yang dimiliki ARD merupakan kunci sukses dalam proses memecahkan masalah (Zimmerman \& Campillo, 2003). Kesalahan yang telah dilakukan seharusnya dapat diantisipasi oleh ARD karena kesalahan tersebut merupakan kesalahan hitung (Mcallister \& Beaver, 2012; Prayitno, dkk., 2018).

Dari proses translasi yang dilakukan ARD di atas, menunjukkan dalam mengubah representasi aljabar ke grafik melibatkan dua metode berbeda representasi simbolik terlebih dahulu baru menuju representasi grafik. Penggunaan representasi yang berbeda menuju representasi target senada dengan penelitian Swastika, dkk. (2020) dan Anwar, dkk., (2016) yang juga melibatkan dua metode berbeda.

Satu hal penting yang harus menjadi perhatian siswa, yaitu menentukan kata kunci dari masalah yang diberikan (Bal, 2014; Prayitno, dkk., 2018). Pada pekerjaan
ARD di atas, kata kunci yang menjadi fokus perhatiannya adalah "tegak lurus". Sehingga ARD mampu menerjemahkannya ke dalam representasi simbolik sebagai perkalian antara kedua gradien garis yang menghasilkan negatif satu (-1).

\section{Simpulan dan Saran}

Proses translasi yang dilakukan siswa dengan kemampuan rendah dari representasi aljabar ke grafik melalui dua metode yang berbeda, yaitu representasi simbolik yang dilanjutkan ke representasi grafik. Translasi memegang peranan penting dalam mengomunikasikan matematika karena pemahaman hubungan antar konsep matematika lebih mudah dipahami.

Penggunaan translasi yang melibatkan berbagai bentuk perlu diajarkan kepada siswa. Tujuannya adalah agar siswa semakin luwes menentukan representasi yang dapat membantunya dalam proses pemecahan berbagai masalah, baik masalah terstruktur maupun tidak terstruktur.

Penelitian ini hanya terbatas pada materi persamaan garis lurus yang diberlakukan pada siswa dengan kemampuan rendah. Untuk itu perlu dilakukan penelitian lebih lanjut, bagaimana proses translasi representasi siswa dengan kemampuan tinggi dan sedang. Selain itu, dapat juga ditinjau berdasarkan gender dan juga kemampuan matematikanya.

\section{Daftar Pustaka}

Adu-Gyamfi, K., Stiff, L. V., \& Bosse, M. J. (2012). Lost in Translation: Examining Translation Errors Assocoated with Mathematical Representations. School Sciences and Mathematics, 112(3), 159-170. https://doi.org/http://doi.org/10.1111/j. 1949-8594.2011.00129x

Anwar, R. B., \& Rahmawati, D. (2017). Symbolic and Verbal Representation Process of Student in Solving Mathematics Problem Based Polya's Stages. International Education Studies, 10(10), 20-28. https://doi.org/10.5539/ies.v10n10p20 
Anwar, R. B., Yuwono, I., As'ari, A. R., Sisworo, \& Rahmawati, D. (2016). Mathematical Representation by Students in Building Relational Understanding on Concepts of Area and Primeter of Rectangle.

Educational Research and Reviewsv, 11(21), 2002-2008. https://doi.org/10.5897/ERR2016.281 3

Bal, A. P. (2014). The Examination of Representations used by Classroom Teacher Candidates in Solving Mathematical Problems. Educational Sciences: Theory \& Practice, 14(6), 2349-2365. https://doi.org/10.12738/estp.2014.6.2 189

Boose, M. J., Adu-Gyamfi, K., \& Chandler, K. (2014). Students' Differentiated Translation Procesess. International Journal for Mathematics Teaching and Learning, 828, 1-28.

Gagatsis, A., \& Shiakalli, M. (2004). Ability to translate from one representation of the concept of function to another and mathematical problem solving. Educational Psychology, 24(5), 645-657. https://doi.org/10.1080/014434104200 0262953

Lesh, R., Post, T., \& Behr, M. (1987). Representations and Translations among Representations in Mathematics Learning and Problem Solving. In Problems of Representation in the Teaching and Learning of Mathematics of Mathematics (pp. 33-40). Hillsdale NJ: Erlbaum.

Mcallister, C. J., \& Beaver, C. (2012). Identification of Error Types in Preservice Teachers 'Attempts to Create Fraction Story Problems for Specified Operations. School Science and Mathematics, 112(2), 88-98.
NCTM. (2000). Principles and Standards for School Mathematics. United States of America: The National Council of Teachers of Mathematics Inc. Retrieved from www.nctm.org

Polya, G. (1973). How to Solve It (2nd ed.). New Jersey: Princeton University Press.

Prayitno, L. L., Purwanto, P., Subanji, S., \& Susiswo, S. (2018). Identification Errors of Problem Posed by Prospective Teachers About Fraction Based Meaning Structure. International Journal of Insights for Mathematics Teaching, 01(1), 76-84. Retrieved from http://journal2.um.ac.id/index.php/ijoi mt/article/viewFile/3018/1828

Sari, D. P., \& Rosjanuardi, R. (2018). Errors of Students Learning with REACT Strategy in Solving the Problems of Mathematical Representation Ability. Journal in Mathematics Education, 9(1), 121128.

Sugiyono. (2018). Metode Penelitian Kuantitatif, Kualitatif, dan R\&D. Bandung: Alfabeta.

Surya, E., Sabandar, J., Kusumah, Y. S., \& Darhim. (2013). Improving of Junior High School Visual Thinking Representation Ability in Mathematical Problem Solving by CTL. Journal in Mathematics Education, 4(1), 113-126. https://doi.org/https://doi.org/10.2234 2/jme.4.1.568.113-126

Swastika, G. T., Nusantara, T., Subanji, \& Irawati, S. (2020). Alteration representation in the Process of Translation Graphic to Graphic. Humanities \& Social Sciences Reviews, 8(1), 334-343. https://doi.org/http://doi.org/10/18510/ hsr.2020.8144

Zimmerman, B. J., \& Campillo, M. (2003). 
76|SIGMA, Volume 5, Nomor 2, Maret 2020, HIm 70-76

Motivating self-regulated problem solvers. In The Psychology of
Problem Solving (pp. 233-262). New

York: Cambridge University Press. 